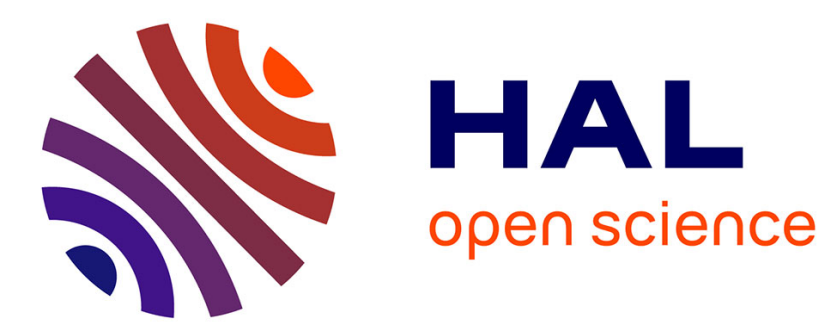

\title{
Five new iridoïd dimers from the fruits of Canthium subcordatum DC (syn. Psydrax subcordata DC)
}

Christelle Joubouhi, Florence Déclaire Mabou, Perrin Lanversin Foning

Tebou, David Ngnokam, Dominique Harakat, Laurence

Voutquenne-Nazabadioko

\section{To cite this version:}

Christelle Joubouhi, Florence Déclaire Mabou, Perrin Lanversin Foning Tebou, David Ngnokam, Dominique Harakat, et al.. Five new iridoïd dimers from the fruits of Canthium subcordatum DC (syn. Psydrax subcordata DC). Phytochemistry Letters, 2015, 13, pp.348-354. hal-01996537

\section{HAL Id: hal-01996537 \\ https://hal.univ-reims.fr/hal-01996537}

Submitted on 22 Sep 2021

HAL is a multi-disciplinary open access archive for the deposit and dissemination of scientific research documents, whether they are published or not. The documents may come from teaching and research institutions in France or abroad, or from public or private research centers.
L'archive ouverte pluridisciplinaire HAL, est destinée au dépôt et à la diffusion de documents scientifiques de niveau recherche, publiés ou non, émanant des établissements d'enseignement et de recherche français ou étrangers, des laboratoires publics ou privés. 


\section{Five new iridoïd dimers from the fruits of Canthium subcordatum DC (syn. Psydrax subcordata DC)}

Christelle JOUBOUHI ${ }^{\text {a }}$, Florence Déclaire MABOU ${ }^{\mathrm{a}}$, Perrin Lanversin FONING TEBOU ${ }^{\mathrm{a}}$, David NGNOKAM ${ }^{\mathrm{a}^{*}}$, Dominique HARAKAT ${ }^{\mathrm{b}}$ and Laurence VOUTQUENNE-

$$
\text { NAZABADIOKO }
$$

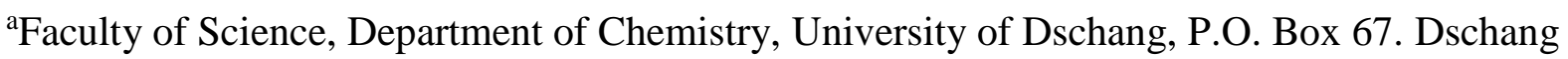
Cameroon

bService Commun d'Analyses, Institut de Chimie Moléculaire de Reims (ICMR), CNRS UMR 7312, Bat. 18 B.P.1039, 51687 Reims Cedex2, France

${ }^{\mathrm{c}}$ Groupe Isolement et Structure, Institut de Chimie Moléculaire de Reims (ICMR), CNRS UMR 7312, Bat. 18 B.P.1039, 51687 Reims Cedex2, France

*Corresponding author. Tel. (237)696710992. E-mail. dngnokam@yahoo.fr 


\begin{abstract}
Five new iridoid dimmers, canthiumosides 1-5 (1-4 and 5a), together with nine known compounds, shanzhigenin methyl ester (6), 1-epishanzhigenin methyl ester (6'), linearin (7), 1-epilinearin ( $\left.\mathbf{7}^{\prime}\right)$, mussaenoside $(\mathbf{8})$, shanzhiside methyl ester $(\mathbf{9}), 3^{\prime}, 4^{\prime}, 7$ - trihydroxyflavone (10), betulinic acid (11), and oleanolic acid (12) were isolated from the fruits of Canthium subcordatum DC (Syn. Psydrax subcordata (DC) Bridson). The structures of these compounds were established by interpretation of their spectral data, mainly HR-TOFESIMS, 1D-NMR $\left({ }^{1} \mathrm{H},{ }^{13} \mathrm{C}\right.$ and DEPT) and 2D-NMR $\left({ }^{1} \mathrm{H}-{ }^{1} \mathrm{H}\right.$ COSY, HSQC, HMBC, and NOESY), and by comparison with the literature.
\end{abstract}

Keywords: Canthium subcordatum/Psydrax subcordata; Rubiaceae; iridoid dimers; canthiumoside; structure elucidation. 


\section{Introduction}

Canthium subcordatum (formely Psydrax subcordata) is a tree which grows in central and western Africa and reaches a height of more than $10 \mathrm{~m}$ (Irvine, 1961). Its roots, leaves and stem bark are used for medicinal purposes (Ampofo, 1977). Alcoholic extracts of the stem bark have potential antidiabetic properties (Ampofo, 1977) and the roots are used to treat malaria fever, inflammation and cardiovascular disease (Awah et al., 2012). Previous work on this genus revealed the presence of iridoids (Achenbach et al., 1980, 1981), peptidic alkaloids (Dongo al., 1989; Achenbach et al., 1986), terpenoids and miscellaneous compounds (Patro et al., 2014). In the course of our continuing search for secondary metabolites of biological importance from Cameroonian medicinal plants, we investigated the $i s o \mathrm{BuOH}, \mathrm{EtOAc}$ and $n$ hexane extracts of the fruits of $C$. subcordatum. In the present paper, we report the isolation and structural elucidation of five new iridoid dimers using chemical and spectroscopic methods.

\section{Results and Discussion}

Purification of the isoBuOH, EtOAc and $n$-hexane soluble fractions of the crude $\mathrm{MeOH}$ extract afforded five new compounds, canthiumosides 1-5 (1-4 and 5a), and nine known compounds (6-12). The structures of the known compounds were determined by means of coTLC and by comparative analysis of their physical and spectral data with those reported in the literature for shanzhigenin methyl ester (6) and 1-epishanzhigenin methyl ester (6') (Guo et al., 2001), linearin (7) and 1-epilinearin (7') (Khatri et al., 1979), mussaenoside (8) (Takeda et al., 1997), shanzhiside methyl ester (9) (Takeda et al., 1997), 3',4',7-trihydroxyflavone (10) (Bickoff et al., 1965), betulinic acid (11) (Sholichin et al., 1980), and oleanolic acid (12) (Hossain et Ismail, 2013) (Figure 1).

Compound 1 (canthiumoside 1) was obtained as a waxy solid. Its HR-TOFESIMS exhibited a pseudo-molecular ion peak at $\mathrm{m} / z 485.1428[\mathrm{M}+\mathrm{Na}]^{+}$(calcd. for $\mathrm{C}_{23} \mathrm{H}_{26} \mathrm{O}_{10} \mathrm{Na}$. 485.1424), indicating the molecular formula $\mathrm{C}_{23} \mathrm{H}_{26} \mathrm{O}_{10}$ with twelve degrees of unsaturation. The ${ }^{1} \mathrm{H}$ and ${ }^{13} \mathrm{C}$ NMR spectra (Tables 1 and 2) showed mainly doubled peaks suggesting that compound $\mathbf{1}$ was an iridoid dimer. The two iridoid moeities are hereafter referred to as units a and $b$. The proton and carbon signals of these two units closely resembled those of the ulmoidosides (Yahara et al., 1990). The ${ }^{1} \mathrm{H}$ NMR spectrum showed four olefinic protons at $\delta_{\mathrm{H}} 7.55$ (H-3a, $\mathrm{s}), \delta_{\mathrm{H}} 7.61(\mathrm{H}-3 \mathrm{~b}, \mathrm{~s})$ and $\delta_{\mathrm{H}} 5.91(\mathrm{H}-7 \mathrm{a}$ and $\mathrm{b}, \mathrm{br} \mathrm{s})$; four methylene protons at $\delta_{\mathrm{H}} 2.06(\mathrm{H}-\alpha-6 \mathrm{a}$ and $\mathrm{b}, \mathrm{m})$ and $\delta_{\mathrm{H}} 2.87(\mathrm{H}-\beta-6 \mathrm{a}$ and $\mathrm{b}, \mathrm{m})$; a methoxy group at $\delta_{\mathrm{H}} 3.73$ (11a-OMe, s); six methine protons at $\delta_{\mathrm{H}} 4.84(\mathrm{H}-1 \mathrm{a}, \mathrm{d}, J=8.6 \mathrm{~Hz}), 4.82(\mathrm{H}-1 \mathrm{~b}, \mathrm{~d}, J=8.6 \mathrm{~Hz}), 3.18(\mathrm{H}-5 \mathrm{a} \mathrm{q}, J=$ 
$8.5 \mathrm{~Hz}), 3.21(\mathrm{H}-5 \mathrm{~b}, \mathrm{q}, J=8.5 \mathrm{~Hz})$ and $\delta_{\mathrm{H}} 2.56(\mathrm{H}-9 \mathrm{a}$ and $\mathrm{b}, \mathrm{t}, J=8.5 \mathrm{~Hz})$; two oxymethylenes at $\delta_{\mathrm{H}} 4.91(\mathrm{H}-10 \mathrm{a}, \mathrm{d}, J=14.4 \mathrm{~Hz}), \delta_{\mathrm{H}} 4.78(\mathrm{H}-10 \mathrm{a}, \mathrm{d}, J=14.4 \mathrm{~Hz}), 4.81(\mathrm{H}-$ $10 \mathrm{~b}, \mathrm{~d}, J=14.5 \mathrm{~Hz})$ and $\delta_{\mathrm{H}} 4.76(\mathrm{H}-10 \mathrm{~b}, \mathrm{~d}, J=14.5 \mathrm{~Hz})$ attributable to an iridoid framework (Patro et al., 2014; Cui-lian et al., 2010; Demirezer et al., 2006) as summarized in Table 1. This was confirmed by the ${ }^{13} \mathrm{C}$ NMR spectrum, which exhibited 23 carbon signals due to 10 pairs of carbons of the main iridoid skeleton (Quang et al., 2002), including two $\alpha, \beta$ unsaturated ester groups at $\delta \mathrm{c} 168.4$ (C-11a) and $\delta \mathrm{c} 167.6(\mathrm{C}-11 \mathrm{~b})$, eight olefinic carbons at $\delta \mathrm{c}$ 153.2 (C-3b), 152.9 (C-3a), 110.2 (C-4a and b), 139.3 (C-8a), 139.1 (C-8b), 129.3 (C-7a) and $\delta$ c 129.7 (C-7b); an acetyl group at $\delta \mathrm{c} 171.3\left(\mathrm{C}-10 \mathrm{~b}-\underline{\mathrm{COCH}}_{3}\right)$ and $\delta_{\mathrm{C}} 19.4\left(\mathrm{C}-10 \mathrm{~b}-\mathrm{COCH}_{3}\right)$ and a methoxyl carbon at $\delta_{\mathrm{C}} 50.3$ (11a-OMe) (Table 2). The two hemiacetal protons at $\delta_{\mathrm{H}}$ $4.82(\mathrm{H}-1 \mathrm{~b})$ and $\delta_{\mathrm{H}} 4.84(\mathrm{H}-1 \mathrm{a})$ correlated in the HSQC spectrum with carbons at $\delta_{\mathrm{C}} 96.3(\mathrm{C}-$ 1b) and 96.2 (C-1a), respectively. Comparison of these chemical shifts with those of linearin (Guo et al., 2001) and shanzhigenin methyl ester (Khatri et al., 1979) indicated that the two hydroxy groups at C-1a and C-1b were not involved in any ether bond.

In the COSY spectrum, protons at $\delta_{\mathrm{H}} 4.82(\mathrm{H}-1 \mathrm{~b})$ and $4.84(\mathrm{H}-1 \mathrm{a})$ correlated with protons at $\delta_{\mathrm{H}} 2.56(2 \mathrm{H}, \mathrm{t}, J=8.5 \mathrm{~Hz})$ attributed to $\mathrm{H}-9 \mathrm{a}$ and $\mathrm{H}-9 \mathrm{~b}$, which correlated to protons at $\delta_{\mathrm{H}} 3.18$ $(\mathrm{H}-5 \mathrm{a}, \mathrm{q}, J=8.5 \mathrm{~Hz})$ and $\delta_{\mathrm{H}} 3.21(\mathrm{H}-5 \mathrm{~b}, \mathrm{q}, J=8.5 \mathrm{~Hz})$. In addition these two protons showed cross peaks with protons at $\delta_{\mathrm{H}} 2.06(\mathrm{H}-6 \alpha \mathrm{a}$ and $\mathrm{H}-6 \alpha \mathrm{b}, \mathrm{m})$ and $\delta_{\mathrm{H}} 2.87(\mathrm{H}-6 \beta \mathrm{a}$ and $\mathrm{H}-6 \beta \mathrm{b}, \mathrm{m})$ which correlated with the olefinic protons at $\delta_{\mathrm{H}} 8.91(\mathrm{H}-7 \mathrm{a}, \mathrm{H}-7 \mathrm{~b})$. The corresponding carbons of these protons were assigned by analysis of the HSQC spectrum (Table 1). In the HMBC spectrum the vinyl protons $\mathrm{H}-7 \mathrm{a}$ and $\mathrm{H}-7 \mathrm{~b}$ showed cross-peaks with carbons at $\delta_{\mathrm{C}} 139.3(\mathrm{C}-$ 8a), 139.1 (C-8b), 38.8 (C-6a), 38.7 (C-6a), 35.9 (C-5a), 36.0 (C-5b) and with the hemiacetal carbons C-1a and C-1b. The protons at $\delta_{\mathrm{H}} 4.78$ and $4.91(\mathrm{H}-10 \mathrm{a}, \mathrm{d}, J=14.4 \mathrm{~Hz})$, showed long-rang correlations with carbon C-7a $(\delta \mathrm{c} 129.3)$. Similarly, protons $2 \mathrm{H}-10 \mathrm{~b}\left(\delta_{\mathrm{H}} 4.76\right.$ and $4.81, \mathrm{~d}, J=14.5 \mathrm{~Hz})$ showed long-rang correlations with carbon C-7b $\left(\delta_{\mathrm{C}} 127.9\right)$. The presence of cross-peaks between $2 \mathrm{H}-10 \mathrm{~b}$ and the carbonyl carbon at $\delta_{\mathrm{C}} 171.2$ revealed the attachment of the acetate to C-10b (Patro et al., 2014; Yahara et al., 1990; Cui-Lian et al., 2010).

In the HMBC spectrum, vinyl proton $\mathrm{H}-3 \mathrm{a}\left(\delta_{\mathrm{H}} 7.55\right)$ correlated with $\mathrm{C}-1 \mathrm{a}\left(\delta_{\mathrm{C}} 96.2\right), \mathrm{C}-4 \mathrm{a}\left(\delta_{\mathrm{C}}\right.$ 110.1), C-11a $\left(\delta_{\mathrm{C}} 168.3\right)$ and $\mathrm{C}-5 \mathrm{a}\left(\delta_{\mathrm{C}} 35.9\right)$ while vinyl proton $\mathrm{H}-3 \mathrm{~b}$ at $\delta_{\mathrm{H}} 7.61$ showed correlations with C-1b ( $\delta \mathrm{c} 96.3), \mathrm{C}-4 \mathrm{~b}\left(\delta_{\mathrm{C}} 110.2\right), \mathrm{C}-11 \mathrm{~b}\left(\delta_{\mathrm{C}} 167.6\right)$ and C-5b $\left(\delta_{\mathrm{C}} 36.0\right)$. The position of the methoxy group $\left(\delta_{\mathrm{C}} 50.3\right)$ was revealed by a cross-peak between the methoxyl protons at $\left(\delta_{\mathrm{H}} 3.73\right)$ and the carbonyl carbon at $\delta_{\mathrm{C}} 168.3$ (C-11a). The position of the ester 
linkage between units a and $\mathrm{b}$ was determined by the presence of cross-peaks between protons $2 \mathrm{H}-10 \mathrm{a}\left(\delta_{\mathrm{H}} 4.91\right.$ and 4.78$)$ and the carbonyl carbon C-11b $\left(\delta_{\mathrm{C}} 167.6\right)$ (Sui-Kiong et al., 2002) Confirmation of the stereochemistry of the stereogenic centers was achieved by analysis of $J$ values and comparison of ${ }^{13} \mathrm{C}$ chemical shifts with literature data, especially those for the chiral centers at C-5a, C-9a and C-5b, C-9b, which indicated the beta-configuration of H-9 as in geniposide (Inouye et al., 1974; Bailleul et al., 1977). The data were also consistent with the normal cis junction between the two rings and the beta-configurations of the hydroxyl residue at C-1 (Hamerski et al., 2003; Zapesochnaya et al., 1991). This was confirmed by NOESY correlations between H-5 and H-9, as well as H-6 $\beta$, in both units. Thus structure 1 was assigned to the iridoid dimmer canthiumoside 1 (Figure 1).

Compound 2 was obtained as a waxy solid. Its HR-TOFESIMS exhibited a pseudo-molecular ion peak at $\mathrm{m} / \mathrm{z} 647.1946[\mathrm{M}+\mathrm{Na}]^{+}$(calcd. for $\mathrm{C}_{29} \mathrm{H}_{36} \mathrm{O}_{15} \mathrm{Na}$. 647.1952), indicating a molecular formula $\mathrm{C}_{29} \mathrm{H}_{36} \mathrm{O}_{15}$ with thirteen degrees of unsaturation. The ${ }^{1} \mathrm{H}$ and ${ }^{13} \mathrm{C}-\mathrm{NMR}$ spectra (Tables 1 and 2) displayed two sets of signals typical of a dimeric iridoid and showed similar chemical shifts to those of compound 1, apart from additional signals for a glucose moiety at $\delta_{\mathrm{H}} 4.74(\mathrm{H}-1$ 'b, d, $J=7.8 \mathrm{~Hz}), 3.24(\mathrm{H}-2$ 'b, dd, $J=9.1,7.8 \mathrm{~Hz}), 3.40(\mathrm{H}-3$ 'b , t,$J=$ 9.1 Hz), 3.31 (H-4'b, m), 3.31 (H-5'b, m), 3.67 (H-6’b, dd, $J=11.7,5.8$ Hz), 3.89 (H-6’b, dd, $J=11.7,1.7 \mathrm{~Hz})$ and at $\delta_{\mathrm{C}} 99.0\left(\mathrm{C}-1^{\prime} \mathrm{b}\right), 73.4\left(\mathrm{C}-2\right.$ 'b), $76.5\left(\mathrm{C}-3^{\prime} \mathrm{b}\right), 70.1(\mathrm{C}-4$ 'b), $77.0(\mathrm{C}-$ 5'b) and 61.4 (C-6'b). Analysis of COSY and HSQC spectra revealed the presence of a glucopyranose moiety (Patro et al., 2014; Cui-Lian et al., 2010) (Tables 1 and 2) characterized by coupling constants up to $7 \mathrm{~Hz}$ for protons $\mathrm{H}-2^{\prime}, \mathrm{H}-3^{\prime}$ and $\mathrm{H}-4$ '. The anomeric configuration of the glucose was determined to be beta from the $J_{\mathrm{H}-1^{\prime}-\mathrm{H}-2^{\prime}}=7.5 \mathrm{~Hz}$ (Kanchanpoom et al., 2002). Acid hydrolysis followed by column chromatography over silica gel with $\mathrm{MeCN} / \mathrm{H}_{2} \mathrm{O}$ as eluent, afforded D-glucose.

The linkage of the glucopyranosyl moiety to $\mathrm{C}-1 \mathrm{~b}$ of the aglycone was clearly indicated by the cross-peak between the anomeric carbon $\left(\delta_{\mathrm{C}} 99.0, \mathrm{C}-1^{\prime} \mathrm{b}\right)$ and $\mathrm{H}-1 \mathrm{~b}\left(\delta_{\mathrm{H}} 5.22, \mathrm{~d}, J=7.7\right.$ $\mathrm{Hz}$ ). Compound 2 afforede the hexa-acetate $\mathbf{2 a}$ on acetylation, confirming the presence of a free hydroxyl group at C-1a. Thus structure 2 was assigned to canthiumoside 2 (Figure 1).

Compound 3, a waxy solid, had a molecular formula $\mathrm{C}_{35} \mathrm{H}_{46} \mathrm{O}_{20}$, deduced from the pseudomolecular ion peak at $\mathrm{m} / z$ 809.2477 $[\mathrm{M}+\mathrm{Na}]^{+}$(calcd. for $\mathrm{C}_{35} \mathrm{H}_{46} \mathrm{O}_{20} \mathrm{Na}$. 809.2480) in its HRTOFESIMS spectrum. The ${ }^{1} \mathrm{H}$ and ${ }^{13} \mathrm{C}-\mathrm{NMR}$ spectra (Tables 1 and 2) displayed two sets of signals typical of a dimeric iridoid and showed similar chemical shifts to those of compound 2, except for the presence of signals of a second hexose moiety. A $\beta$-glucopyranose moiety was identified starting from the anomeric proton at $\delta_{\mathrm{H}} 4.73(\mathrm{H}-1$ 'a, $\mathrm{d}, J=7.8 \mathrm{~Hz})$ in the 
COSY spectrum (Patro et al., 2014; Cui-Lian et al., 2010) and confirmed by the carbon chemical shifts (Kanchanpoom et al., 2002). Again acid hydrolysis afforded only $D$-glucose. The attachment of the second glucopyranose moiety to C-1a was clearly indicated by the cross-peak between the anomeric carbon $\left(\delta_{\mathrm{C}} 98.9, \mathrm{C}-1\right.$ 'a) and $\mathrm{H}-1 \mathrm{a}$ at $\delta_{\mathrm{H}} 5.24$. In addition, comparison of the ${ }^{13} \mathrm{C}$ data of $\mathbf{3}$ with those of related compounds (Zeng et al., 2010) supported structure 3 for canthiumoside 3 (Figure 1).

Compound 4 was obtained as a waxy solid. Its HR-TOFESIMS exhibited a pseudo-molecular ion peak at $m / z 767.2369[\mathrm{M}+\mathrm{Na}]^{+}$(calcd. for $\mathrm{C}_{33} \mathrm{H}_{44} \mathrm{O}_{19} \mathrm{Na}$. 767.2374), indicating that the molecular formula $\mathrm{C}_{33} \mathrm{H}_{44} \mathrm{O}_{19}$ and twelve degree of unsaturation. The ${ }^{1} \mathrm{H}$ and ${ }^{13} \mathrm{C}$ NMR spectra were very similar to those of $\mathbf{3}$, except the absence of the acetyl group at C-10b. Acid hydrolysis again afforded only $D$-glucose. Structure 4 for canthiumoside 4 (Figure 1) was also supported by the literature data of related compounds (Zeng et al., 2010).

Compound $\mathbf{5}$ was obtained pure only as its acetate $\mathbf{5 a}$ and its structure elucidation was carried out with the acetate. However, NMR spectra of the mixture containing the compound $\mathbf{5}$ were in complete agreement with the proposed structure. The general appearance of the ${ }^{1} \mathrm{H}$ and ${ }^{13} \mathrm{C}$ NMR spectra of the mixture suggested that $\mathbf{5}$ was an iridoid dimmer with a glycosyl moiety. The ${ }^{1} \mathrm{H}$ NMR spectrum contained three hemiacetal proton doublets whose HMBC correlations were also consistent with a dimeric iridoid skeleton. Comparison with NMR data of compounds $\mathbf{2}$ and $\mathbf{3}$ showed that compound $\mathbf{5}$ possessed the same unit a glucosylated at C-1a but differed in the structure of unit b. The HR-TOFESIMS of the pentaacetate 5a showed a pseudo-molecular ion peak at $\mathrm{m} / z 801.2592[\mathrm{M}+\mathrm{Na}]^{+}$(calcd. 801.2582) corresponding to the elemental composition $\mathrm{C}_{37} \mathrm{H}_{46} \mathrm{O}_{18}$. This was consistent with the ${ }^{13} \mathrm{C}$ NMR spectrum which displayed thirty seven carbons (Table 2). The ${ }^{1} \mathrm{H}$ NMR spectrum contained six methyl signals, five of which at $\delta_{\mathrm{H}}$ 2.15, 2.11, 2.05, 2.02 and 1.99 were due to acetates. The structure of 5a was confirmed by analysis of the 2D NMR (COSY, HSQC and HMBC) data. A betaglucopyranose moiety was identified in the COSY spectrum starting from the anomeric proton at $\delta_{\mathrm{H}} 4.90(\mathrm{H}-1$ ' $\mathrm{a}, J=7.9 \mathrm{~Hz})$. The expected $\mathrm{HMBC}$ correlations confirmed that unit a, with a glucopyranose unit attached to $\mathrm{C}-1 \mathrm{a}$, was the same as in compounds 1-4 and was connected to unit b via the same ester link. In the COSY spectrum, $\mathrm{H}-1 \mathrm{~b}$ at $\delta_{\mathrm{H}} 6.05(\mathrm{~d}, J=7.7$ $\mathrm{Hz}$ ) correlated with $\mathrm{H}-9 \mathrm{~b}\left(\delta_{\mathrm{H}} 2.25\right)$ which, in turn, showed a cross-peak with $\mathrm{H}-8 \mathrm{~b}\left(\delta_{\mathrm{H}} 2.35\right)$. A further cross-peak from $\mathrm{H}-8 \mathrm{~b}$ to a methyl group Me-10b $\left(\delta_{\mathrm{H}} 1.05, \mathrm{~d}, J=5.1 \mathrm{~Hz}\right)$ revealed the structure of unit b. The assignments of all the protons and carbons of unit B followed readily from analysis of the HMBC spectrum (Tables 1 and 2). The relative stereochemistry 
of 5a was supported by its NOESY spectrum which showed correlations between $\mathrm{H}-5 \mathrm{~b} \beta$ and $\mathrm{H}-9 \mathrm{~b} \beta$, and between Me-10b and $\mathrm{H}-1 \mathrm{~b} \alpha$ showing that the methyl group is alpha. Comparison of the ${ }^{13} \mathrm{C}$ data of $\mathbf{5 a}$ with those of related compounds S(Zhang et al., 2009) supported structure 5 for canthiumoside 5 (Figure 1).

\section{Experimental}

\subsection{General}

The melting points were recorded with a Reichert microscope (Reichert Technologies, Depew, New York USA) and are uncorrected. IR spectra were recorded with a Shimadzu FTIR-8400S (Shimadzu, France) spectrophotometer. ${ }^{1} \mathrm{H}(500 \mathrm{MHz})$ and ${ }^{13} \mathrm{C}(125 \mathrm{MHz}) \mathrm{NMR}$ spectra were recorded on a BRUKER Avance DRX-500 spectrometer (Bruker, Wissembourg, France) equipped with a BBFO+5 mm probe. ${ }^{1} \mathrm{H}(600 \mathrm{MHz})$ and ${ }^{13} \mathrm{C}(150 \mathrm{MHz}) \mathrm{NMR}$ spectra were recorded on a BRUKER Avance III-600 spectrometer (Bruker, Wissembourg, France) equipped with a cryoplatform using $\mathrm{CD}_{3} \mathrm{OD}$ with TMS as the internal standard. TOFESIMS and HR-TOF-ESI experiments were performed using a Micromass Q-TOF micro instrument (Manchester, UK) with an electrospray source. The samples were introduced by direct infusion in a solution of $\mathrm{MeOH}$ at a rate of $5 \mu \mathrm{min}^{-1}$. The optical rotations were measured on a Bellingham \& Stanley ADP 220) polarimeter (Bellingham + Stanley Ltd, United King-Dom). Column chromatography was run on Merck silica gel (VWR, France ) 60 (70-230 mesh) and gel permeation on Sephadex LH-20 (VWR, France), while TLC was carried out on silica gel $\mathrm{GF}_{254}$ pre-coated plates with detection accomplished by spraying with $50 \% \mathrm{H}_{2} \mathrm{SO}_{4}$ followed by heating at $100{ }^{\circ} \mathrm{C}$ or by visualizing with a UV lamp at 254 and 365 $\mathrm{nm}$.

\subsection{Plant material}

The fruits of Canthium subcordatum DC (syn. Psydrax subcordata DC Bridson) were collected in Foto village (Menoua Division, Western region of Cameroon), in April 2012. Authentication was performed by Victor Nana, a botanist of the Cameroon National Herbarium, Yaoundé, where a voucher specimen ( ${ }^{\circ}$ 19579/SRF/CAM) has been deposited.

\subsection{Extraction and isolation}

The dried fruits of $C$. subcordatum $(3.5 \mathrm{~kg}$ ) were extracted with $\mathrm{MeOH}$ at room temperature for 3 days, and the extract was concentrated to dryness under reduced pressure $(130 \mathrm{~g})$. Part of the residue (122 g) was suspended in water and successively extracted with $n$ hexane, ethyl acetate and isobutanol to obtain, after evaporation of solvent, $53.8 \mathrm{~g}, 6.6 \mathrm{~g}$ and $35 \mathrm{~g}$ respectively. Part of the isobutanol-solute extract (32 g) was subjected to silica gel CC eluting with EtOAc containing increasing $\mathrm{MeOH}(0 \%, 5 \%, 10 \%, 15 \%, 20 \%$ and $30 \%$, each 
$500 \mathrm{ml}$ ) to give eight sub fractions (A to $\mathrm{H})$. Fraction D $(6.6 \mathrm{~g})$ was purified by silica gel CC eluting with an EtOAc- $\mathrm{MeOH}(5 \%)$ mixture to give compound 8 (40 mg). Fraction $\mathrm{H}(8 \mathrm{~g})$ was purified by silica gel $\mathrm{CC}$ eluting with an EtOAc-MeOH (15\%) mixture to give compounds 4 (39 mg) and 3 (42 mg). G (1.4 g) was purified by silica gel CC eluting with an EtOAc-MeOH (15\%) mixture to give compound 9 (36 mg). Fractions A to C were combined with the EtOAc-soluble extract $(8.6 \mathrm{~g})$ and the whole was eluted with $n$-hexane containing increasing EtOAc $(0 \%, 5 \%, 10 \%, 15 \%, 20 \%, 30 \%$ and 70\%), EtOAc and EtOAc-MeOH (5\%) mixtures. Eight sub fractions, 1-8, were obtained. Fraction $5(1.5 \mathrm{~g})$ was purified by silica gel CC eluting with a Hex-EtOAc (15\%) mixture to give compounds 1 (24 mg) and 7 (35 mg). Fraction 6 (430 mg) was purified by silica gel CC eluting with a Hex-EtOAc (80\%) mixture to give compound $2(36 \mathrm{mg})$. Fraction $7(2 \mathrm{~g})$ was purified by silica gel CC eluting with a $n$ Hex-EtOAc (40\%) mixture to give compounds 10 (22 mg), 6 and 6' (32 mg). Fraction 8, containing compound $\mathbf{5}$, could not be purified and was acetylated (acetic anhydridre:pyridine 1:1). The pentaacetate 5a was isolated by silica gel CC. Part of $n$-hexane-solute extracts $(50 \mathrm{~g})$ was eluted with $n$-hexane containing increasing EtOAc $(0 \%, 10 \%, 20 \%, 30 \%, 60 \%)$, EtOAc and EtOAc-MeOH (5\%) mixtures to give five sub fractions A to E. The portion eluted with $20 \%$ ethyl acetate in $n$-hexane (fraction C) was chromatographed over silica gel with the same system to give compounds $\mathbf{1 1}(50 \mathrm{mg})$ and $\mathbf{1 2}(40 \mathrm{mg})$.

\subsection{New Compound Data}

Canthiumoside 1 1. Waxy solid, $[\alpha]_{\mathrm{D}}^{23}-43.2$ (c $\left.0.50, \mathrm{MeOH}\right)$. IR $(\mathrm{NaCl}) v_{\max }\left(\mathrm{cm}^{-1}\right): 3500$; 1754; 1640; 1602. ${ }^{1} \mathrm{H}(500 \mathrm{MHz})$ and ${ }^{13} \mathrm{C}-\mathrm{NMR}(125 \mathrm{MHz})$ data in $\mathrm{CD}_{3} \mathrm{OD}$ see Tables 1 and 2. HR-TOFESIMS $m / z: 485.1428[\mathrm{M}+\mathrm{Na}]^{+}$(calcd. for $\mathrm{C}_{23} \mathrm{H}_{26} \mathrm{O}_{10} \mathrm{Na}, 485.1424$ )

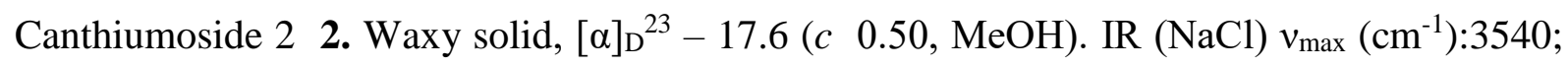
1744; $1643 ; 1622 .{ }^{1} \mathrm{H}(600 \mathrm{MHz})$ and ${ }^{13} \mathrm{C}-\mathrm{NMR}(150 \mathrm{MHz})$ data in $\mathrm{CD}_{3} \mathrm{OD}$, see Tables 1 and 2. HR-TOFESIMS $m / z: 647.1946[\mathrm{M}+\mathrm{Na}]^{+}$(calcd. for $\mathrm{C}_{29} \mathrm{H}_{36} \mathrm{O}_{15} \mathrm{Na}, 647.1952$ )

Canthiumoside 3 3. Waxy solid, $[\alpha]_{\mathrm{D}}^{23}-0.6$ (c 0.46, MeOH). IR $(\mathrm{NaCl}) v_{\max }\left(\mathrm{cm}^{-1}\right): 3500$; 1754; 1630; 1612. ${ }^{1} \mathrm{H}(500 \mathrm{MHz})$ and ${ }^{13} \mathrm{C}-\mathrm{NMR}(125 \mathrm{MHz})$ data in $\mathrm{CD}_{3} \mathrm{OD}$, see Tables 1 and 2. HR-TOFESIMS $m / z: 809.2477[\mathrm{M}+\mathrm{Na}]^{+}$(calcd. for $\mathrm{C}_{35} \mathrm{H}_{46} \mathrm{O}_{20} \mathrm{Na}, 809.2480$ )

Canthiumoside 4 4. Waxy solid, $[\alpha]_{\mathrm{D}}^{23}-3.9$ (c $\left.0.55, \mathrm{MeOH}\right)$. IR $(\mathrm{NaCl}) v_{\max }\left(\mathrm{cm}^{-1}\right): 3550$; 1750; 1645; 1610. ${ }^{1} \mathrm{H}(500 \mathrm{MHz})$ and ${ }^{13} \mathrm{C}-\mathrm{NMR}(125 \mathrm{MHz})$ data in $\mathrm{CD}_{3} \mathrm{OD}$, see Tables 1 and 2. HR-TOFESIMS $m / z: 767.2369[\mathrm{M}+\mathrm{Na}]^{+}$(calcd. for $\mathrm{C}_{33} \mathrm{H}_{44} \mathrm{O}_{19} \mathrm{Na}, 767.2374$ )

Canthiumoside 5a 5a. Waxy solid, $[\alpha]_{\mathrm{D}}^{23}-11.2\left(c 0.50, \mathrm{CHCl}_{3}\right)$. IR $(\mathrm{NaCl}) v_{\max }\left(\mathrm{cm}^{-1}\right): 1754$; 1640; 1602. ${ }^{1} \mathrm{H}(600 \mathrm{MHz})$ and ${ }^{13} \mathrm{C}-\mathrm{NMR}(150 \mathrm{MHz})$ data in $\mathrm{CDCl}_{3}$, see Tables 1 and 2. HRTOFESIMS $m / z: 801.2592[\mathrm{M}+\mathrm{Na}]^{+}$(calcd. for $\mathrm{C}_{37} \mathrm{H}_{46} \mathrm{O}_{18} \mathrm{Na}, 801.2582$ ) 


\subsection{Acetylation of 2, 6 and 6', 7 and 7'}

Compound $2(13 \mathrm{mg})$ was acetylated with $\mathrm{Ac}_{2} \mathrm{O}$-pyridine and the reaction mixture was purified over a silica gel column, eluting with a Hex-EtOAc (20\%) mixture to give compound 2a (Waxy solid, $6 \mathrm{mg}) \cdot[\alpha]_{\mathrm{D}}^{23}-14.1\left(c 0.58, \mathrm{CHCl}_{3}\right)$. IR $(\mathrm{NaCl}) v_{\max }\left(\mathrm{cm}^{-1}\right): 1754 ; 1640$; 1602. HR-TOFESIMS $m / z: 857.2488[\mathrm{M}+\mathrm{Na}]^{+}$(calcd. for $\mathrm{C}_{39} \mathrm{H}_{46} \mathrm{O}_{20} \mathrm{Na}, 857.2480$ ). ${ }^{1} \mathrm{H}$ NMR $\left(\mathrm{CDCl}_{3}, 600 \mathrm{MHz}\right) \delta_{\mathrm{H}}: 7.91(1 \mathrm{H}, \mathrm{s}, \mathrm{H}-3 \mathrm{~b}), 7.48(1 \mathrm{H}, \mathrm{s}, \mathrm{H}-3 \mathrm{a}), 5.94(1 \mathrm{H}, \mathrm{d}, 6.9, \mathrm{H}-1 \mathrm{a}), 5.92$ (1H, br s, H-7a), 5.92 (1H, br s, H-7b), 5.88 (1H, d, 7.4, H-1b), 5.25 (1H, t, 9.3, H-3’b), 5.15 (1H, dd, 9.5, 9.3, H-4’b), 5.05 (1H, dd, 8.1, 9.3, H-2’b), 4.90 (1H, d, 8.1, H-1'b), 4.86 (1H, d, 13.5, H-10b), 4.85 (1H, d, 13.7), 4.72 (1H, d, 13.7, H-10a), 4.70 (1H, d, 13.5, H-10b), 4.27 (1H, dd, 13.0, 2.4), 4.16 (1H, dd, 13.0, 5.9, H-6’b), 3.75 (3H, s, C-11a -OMe), 3.75 (1H, m, H-5’b), 3.30 (1H, m, H-5a), 3.23 (1H, m, H-5b), 2.90 (1H, m, H-6- $\beta-\mathrm{a}), 2.89$ (1H, t, 7.4, H9b), 2.88 (1H, t, 8.2, H-9a), 2.87 (1H, m, H-6- $\beta-b), 2.20$ (1H, m, H-6- $\alpha-a), 2.18$ (3H, s, C-1aOAc). ${ }^{13} \mathrm{C}$ NMR $\left(\mathrm{CDCl}_{3}, 150 \mathrm{MHz}\right) \delta_{\mathrm{C}}: 170.6$ (C-10b-OAc), 170.5 (C-6'-OAc), 170.2 (C-3'OAc), 169.4 (C-4'-OAc), 169.3 (C-1a-OAc), 169.1 (C-2'-OAc), 167.2 (C-11a), 166.4 (C11b), 151.6 (C-3a), 151.4 (C-3b), 137.2 (C-8b), 136.6 (C-8a), 132.3 (C-7a), 130.8 (C-7b), 111.7 (C-4b), 111.3 (C-4a), 96.9 (C-1'b), 96.1 (C-1b), 91.5 (C-1a), 72.4 (C-3'), 72.0 (C-5’b), 70.7 (C-2’b), 68.2 (C-4’b), 62.5 (C-10b), 61.6 (C-6’b), 61.5 (C-10a), 51.4 (C-11a-OMe), 46.7 (C-9b), 45.3 (C-9a), 38.6 (C-6b), 38.4 (C-6a), 34.4 (C-5a), 34.0 (C-5b), 20.7 (C-4'-OAc; C6'-OAc), 20.6 (C-3'-OAc), 20.5 (C-10b-OAc; C-1a-OAc), and 20.3 (C-2'-OAc).

Mixture 6 and 6' (30 mg) was acetylated with $\mathrm{Ac}_{2} \mathrm{O}$-pyridine and the reaction mixture was purified over a silica gel column, eluting with a Hex-EtOAc (20\%) mixture to give only the compound 6a (Waxy solid, $10 \mathrm{mg}$ ). IR (NaCl) $v_{\max }\left(\mathrm{cm}^{-1}\right)$ : 3500; 1754; 1640; 1602. HRTOFESIMS $m / z: 309.0943[\mathrm{M}+\mathrm{Na}]^{+}$(calcd. for $\left.\mathrm{C}_{13} \mathrm{H}_{18} \mathrm{O}_{7} \mathrm{Na}, 309.0950\right)$. ${ }^{1} \mathrm{H} \mathrm{NMR}\left(\mathrm{CDCl}_{3}\right.$, $500 \mathrm{MHz}) \delta_{\mathrm{H}}: 7.38(1 \mathrm{H}, \mathrm{s}, \mathrm{H}-3), 6.15(1 \mathrm{H}, \mathrm{d}, 7.4, \mathrm{H}-1), 4.13(1 \mathrm{H}, \mathrm{m}, \mathrm{H}-6), 3.74$ (3H, s, C11- $\left.\mathrm{OCH}_{3}\right), 3.09$ (1H, m, H-5), 2.66 (1H, t, 7.4, H-9), 2.10 (3H, s, C-1-OAc) $2.04(1 \mathrm{H}, \mathrm{m}$,

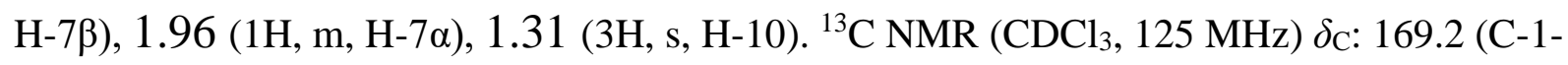
OAc), 168.1 (C-11), 151.2 (C-3), 109.8 (C-4), 89.5 (C-1), 78.8 (C-6), 77.0 (C-8), 50.7 (C-11-OMe), 50.1 (C-9), 47.1 (C-7), 41.3 (C-5), 23.8 (C-1-OAc), 20.9 (C-10),

Mixture 7 and 7' (120 mg) was acetylated with $\mathrm{Ac}_{2} \mathrm{O}-$ pyridine and the reaction mixture was purified over a silica gel column, eluting with a Hex-EtOAc (80\%) mixture to give compounds $7 \mathbf{a}(20 \mathrm{mg})$ and $7 \mathbf{b}(30 \mathrm{mg})$.

Compound 7a was obtained as a waxy solid. IR (NaCl) $v_{\max }\left(\mathrm{cm}^{-1}\right): 3500 ; 1754 ; 1640$; 1602. HR-TOFESIMS $m / z: 293.1006[\mathrm{M}+\mathrm{Na}]^{+}$(calcd. for $\mathrm{C}_{13} \mathrm{H}_{18} \mathrm{O}_{6} \mathrm{Na}, 293.1001$ ). ${ }^{1} \mathrm{H} \mathrm{NMR}$ 
$\left(\mathrm{CDCl}_{3}, 600 \mathrm{MHz}\right) \delta_{\mathrm{H}}: 7.35(1 \mathrm{H}, \mathrm{s}, \mathrm{H}-3), 6.15(1 \mathrm{H}, \mathrm{d}, 7.3, \mathrm{H}-1), 3.74\left(3 \mathrm{H}, \mathrm{s}, \mathrm{C}-11-\mathrm{OCH}_{3}\right)$, 3.21 (1H, m, H-5), 2.35 (1H, m, H-6), 2.29 (1H, t, 8.5, H-9), 2.10 (3H, s, C-1-OAc), 1.73

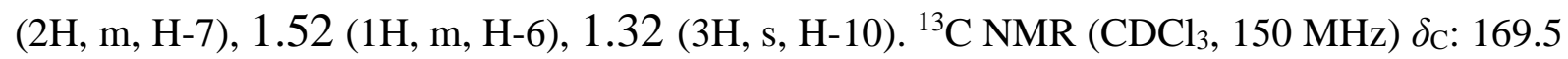
(C-1-OAc), 167.2 (C-11), 150.2 (C-3), 112.0 (C-4), 89.8 (C-1), 79.6 (C-8), 51.3 (C-9), 50.1 (C-11-OMe), 40.3 (C-7), 30.5 (C-5), 29.5 (C-6), 24.3 (C-10), 21.5 (C-1-OAc).

Compound 7b was obtained as a waxy solid. ${ }^{1} \mathrm{H}$ and ${ }^{13} \mathrm{C}$ NMR spectra showed similar chemical shifts to those of compound 7a except for the additional peaks of an acetyl group, due to acetylation of the tertiary hydroxyl group at C-8. IR $(\mathrm{NaCl}) v_{\max }\left(\mathrm{cm}^{-1}\right): 1754 ; 1640$; 1602. HR-TOFESIMS $m / z: 335.1111[\mathrm{M}+\mathrm{Na}]^{+}$(calcd. for $\left.\mathrm{C}_{15} \mathrm{H}_{20} \mathrm{O}_{7} \mathrm{Na}, 335.1107\right]$. ${ }^{1} \mathrm{H} \mathrm{NMR}$ $\left(\mathrm{CDCl}_{3}, 600 \mathrm{MHz}\right) \delta_{\mathrm{H}:} 7.41(1 \mathrm{H}, \mathrm{s}, \mathrm{H}-3), 6.15(1 \mathrm{H}, \mathrm{d}, 7.5, \mathrm{H}-1), 3.75(3 \mathrm{H}, \mathrm{s}, \mathrm{C}-11-\mathrm{OMe})$, 3.16 (1H, m, H-5), 2.68 (1H, t, 7.5, H-9), 2.30 (1H, m, H-6), 2.10 (3H, s, C-1-OAc), 2.05 (1H, m, H-7), 2.04 (3H, m, C-8-OAc) 1.85 (1H, m, H-7), 1.55 (3H, s, H-10), 1.39 (1H, m, H-6). ${ }^{13} \mathrm{C} \mathrm{NMR}\left(\mathrm{CDCl}_{3}, 150 \mathrm{MHz}\right) \delta_{\mathrm{C}}: 170.7$ (C-8-OAc), 169.2 (C-1-OAc), 166.9 (C-11), 151.2 (C3), 111.0 (C-4), 89.5 (C-1), 88.6 (C-8), 51.3 (C-11-OMe), 48.7 (C-9), 38.5 (C-7), 30.9 (C-5), 28.8 (C-6), 22.2 (C-8-OAc), 21.0 (C-1-OAc), 20.5 (C-10).

\subsection{Acid Hydrolysis}

$15 \mathrm{mg}$ of each compound (2-4) was individually refluxed in $2 \mathrm{~N} \mathrm{HCl}(5.0 \mathrm{~mL})$ at $80{ }^{\circ} \mathrm{C}$ for 3h. Each reaction mixture was extracted with $\mathrm{CHCl}_{3}(3 \times 5 \mathrm{~mL})$, and the $\mathrm{H}_{2} \mathrm{O}$ phase was dried using a $\mathrm{N}_{2}$ stream (Gournelis et al., 1989). The residues were separately subjected to CC over silica gel with $\mathrm{MeCN} / \mathrm{H}_{2} \mathrm{O}(8: 1)$ as the eluent to yield glucose $(2 \mathrm{mg}, 3.3 \mathrm{mg}$ and $3.5 \mathrm{mg}$ respectively), $[\alpha]^{20}{ }_{\mathrm{D}}+35.9\left(c 1.0, \mathrm{H}_{2} \mathrm{O}\right)$. The solvent system $\mathrm{MeCN} / \mathrm{H}_{2} \mathrm{O}(6: 1)$ was used for TLC identification of glucose (Zhang et al., 2008).

\section{Acknowledgments}

The authors thank the University of Dschang, the "Région Champagne-Ardenne and the Département de la Marne" for financial support. The EU-programme FEDER to the PIANET CPER project is also gratefully acknowledged.

\section{References}

Achenbach, H. 1986. Investigations on West African medicinal plants. Pure and Apllied Chemistry 58, 653-662

Achenbach, H., Waibel R., Addae-mensah I., 1980. Shanzhisin methyl ester gentiobioside, a new iridoid-isolation and synthesis. Tetrahedron Letters 21, 3677-3678 
Achenbach, H., Waibel R., Addae-mensah I., 1981. Iridoid and other constituents of Canthium subcordatum. Phytochemistry 20, 1591-1595.

Ampofo, O., 1977. Paper read at the Third Symposium of Medicinal Plants, Ife, Nigeria.

Awah F.M., Uzoegwu, P.N., Ifeonu, P., Oyugi, J. O., Rutherford, J., Yao, X.J., Fehrmann, F., Fowke, K.R., Eze, M.O. 2012. Free radical scavenging activity, phenolic contents and cytotoxicity of selected Nigerian medicinal plants. Food Chemistry 13, 1279-1286.

Bailleul, F., Delaveau, P., Rbaron, A., Plat, M., Koch, M., 1977. Feretoside and gardenoside from Feretia apodanthera, ${ }^{13} \mathrm{C}-\mathrm{NMR}$ spectra iridoïd series. Phytochemistry 16, 723-726.

Bickoff, E.M., Witt, S.C., Livingston, A.L., 1965. 3',4',7-hydroxyflavone in Alfalfa. Journal of Pharmaceutical Sciences. 54, 1555.

Cui-Lian, F., Ming-Fu, G., Yan-Bo, Z., Hao-Fu, D., Wen-Li, M., 2010. Scyphiphinc, a new Iridoid from Scyphiphora hydrophyllacea. Molecules 15, 2473-2477.

Demirezer, O.L., Gürbüz, F., Güvernalp, Z., Ströch, K., Zeeck,A., 2006. Iridoïds, flavonoids and monoterpene glycosides, from Galium verum subsp. Verum. Turk. Journal of Chemistry 30, 525-534.

Dongo E., Ayafor, J.F., Sondengam B.L., Connoly J.D., 1989 A new peptide alkaloïd from Canthium arnoldianum. Journal of Natural Products 52, 840-843.

Gournelis, D., Skaltsounis, A.L, Tillequin, F., Koch, M., 1989. Plantes de NouvelleCalédonie, CXXI. Iridoïdes et alcaloïdes de Plectronia odorata. Journal of Natural Products 52, 306-316.

Guo, S.J., Gao, L.M., Cheng, D.L., 2001. Iridoid from Phlomis umbrosa. Pharmazie 98, 178180.

Hamerski, L., Furlan, M., Siqueira, D.H., Cavalheiro, A.J., Nogueira, M., Tomazela, D.M., Bolzani, V.S., 2003. Iridoïd glucosides from Randia spinosa (Rubiaceae). Phytochemistry $63,397-400$

Hossain, A.M., Ismail, Z., 2013. Isolation and characterization of triterpenes from the leaves of Orthosiphon stamineus. Arabian Journal of Chemistry 6, 295-298.

Inouye, H., Takeda, Y., Nishimura, H., 1974. Two new iridoïd glucosides from Gardenia jasminoides fruits. Phytochemistry 13, 2219-2224.

Irvine, F. R., 1961. Woody Plants of Ghana. Oxford University Press, London, p 658.

Kanchanpoom, T., Kasai, R., Chumsri, P., Yamasaki, K., 2002. Iridoïd glucosides from Thumbergia laurifolia. Phytochemistry 60, 769-771.

Khatri, L.M., Kazi, M.A., 1979. Chemical investigation of Aticharis linearis Hochst, Part- II (structure of linearin and linearoside). Journal of Chemical Society of Pakistan. 1, 25-28. 
Patro, S.K., Sasmal, D., Mazumndar, P., Behera, P., Lal, U.R., Dash, S.K., Padhy, R.K., 2014. Review on genus Canthium: Special reference to Canthium coromandelicum-an unexplored traditional medicinal plant of Indian Subcontinent. American Journal of Phytomedicine and Clinical Therapeuties 2, 796-813.

Sholichin M., Yamasaki, K., Kasai, R., Tanaka, O., 1980. ${ }^{13}$ C-Nuclear magnetic resonance of lupane type triterpenes. Lupeol, betulin and betulinic acid. Chemical and Pharmaceutical Bulletin. 28, 1006-1008.

Sui-Kiong, L., Akiko, K., Takashi, T., Toshihiro, F., Kunihide, M., Asao, K., 2002. Iridoïds and anthraquinones from the Malaysian Medicinal Plant, Saprosmas cortechnii (Rubiaceae). Chemical and Pharmaceutical Bulletin. 50, 1035-1040.

Takeda, Y., Nishimura, H., Inouye, H., 1997. Two new iridoid glucosides from Mussaenda parviflora and Mussaenda shikokinia. Phytochemistry 16, 1401-1404.

Yahara, S., Kato, K., Nakazawa, Y., Toda, Y. Nohara, T., 1990. New iridoïds trimmers and tetramers from seeds of Eucommia ulmoides. Chemical and Pharmaceutical Bulletin. 38, 267-269.

Zapesochnaya, G.G., Kurkin, V.A., Pervykh, I.N., Karasartov, B.S., 1991. Velpetin-a new iridoid glycoside from Nepeta velutina. Khimija Prirodnykh Soedineny 6, 777-781.

Zeng, Y.B., Mei, W.L., Wang, H., Li, X.N., Dai, H.F., 2010. Scyphiphin D, a new iridoid glucoside dimer from Scyphiphora hydrophyllacea. Journal of Asian Natural Products Research 12, 1010-1014.

Zhang, F., Sun, L., Chen, W.S., 2009. A new iridoid glucoside from Lamiophlomis rotata. Chemistry of Natural Compounds 45, 360-362.

Zhang, Y., Gan, M., Lin, S., Liu, M., Song, W., Zi, J., Wang, S. Li, S., Yang, Y., Shi, J., 2008. Glycosides iridoïd from the bark of Adina polycephala. Journal of Natural Products 71, 905-909. 
Table 1: ${ }^{1} \mathrm{H}-\mathrm{NMR}$ Spectral data of Compounds $\mathbf{1 - 4}\left(\mathrm{CD}_{3} \mathrm{OD}\right)$ and $\mathbf{5 a}\left(\mathrm{CDCl}_{3}\right)$

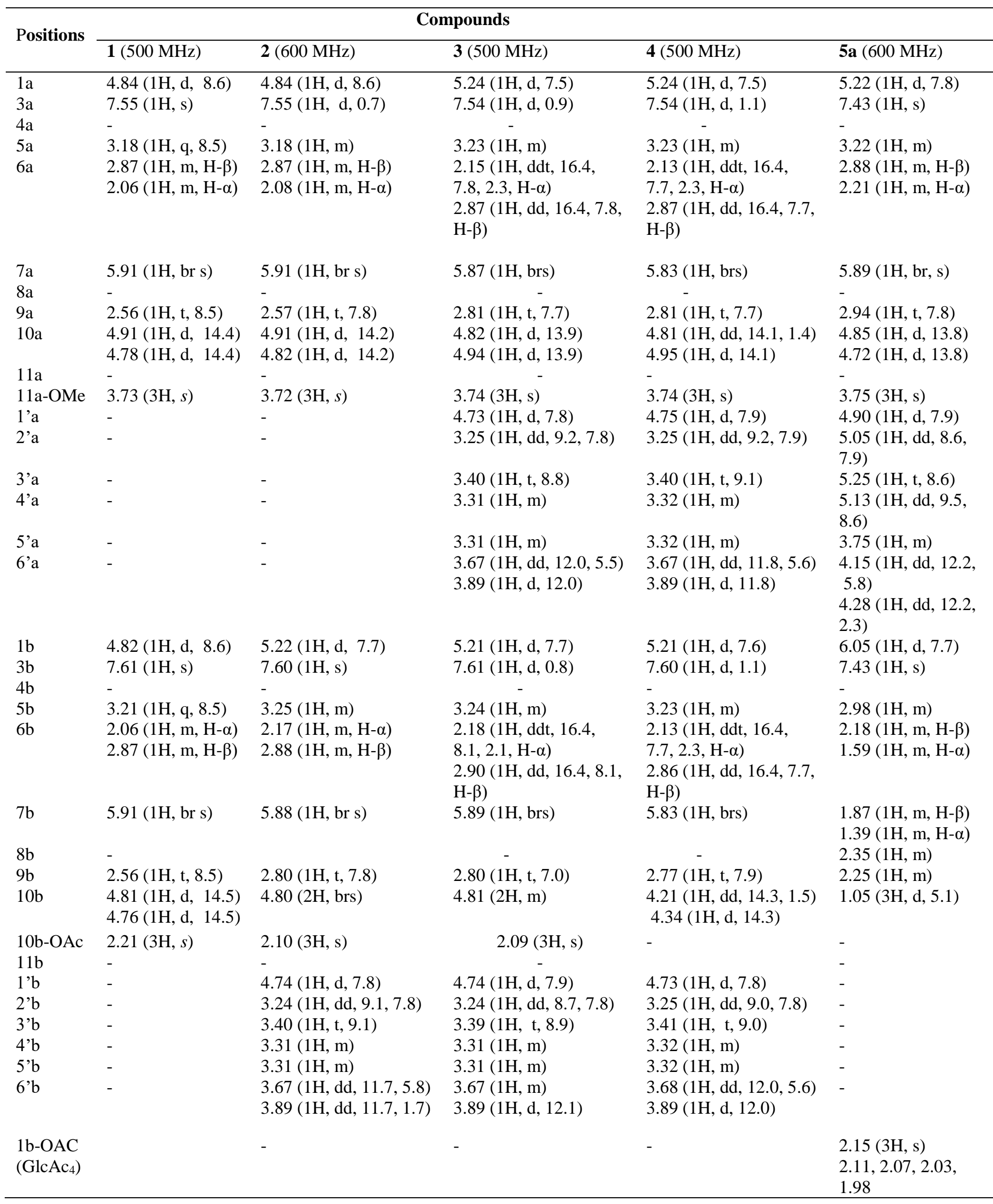


Table 2: ${ }^{13} \mathrm{C}-\mathrm{NMR}$ Spectral data of Compounds 1-4 $\left(\mathrm{CD}_{3} \mathrm{OD}\right)$ and $\mathbf{5 a}\left(\mathrm{CDCl}_{3}\right)$

\begin{tabular}{|c|c|c|c|c|c|}
\hline \multirow{2}{*}{ Positions } & \multicolumn{4}{|c|}{ Compounds } & \multirow[b]{2}{*}{ 5a (150 MHz) } \\
\hline & $\mathbf{1}(125 \mathrm{MHz})$ & $2(150 \mathrm{MHz})$ & $3(125 \mathrm{MHz})$ & $4(125 \mathrm{MHz})$ & \\
\hline $1 \mathrm{a}$ & 96.2 & 96.1 & 96.8 & 96.8 & 95.5 \\
\hline $3 a$ & 152.9 & 152.9 & 151.9 & 152.0 & 150.9 \\
\hline $4 a$ & 110.2 & 110.1 & 111.0 & 111.0 & 112.1 \\
\hline $5 \mathrm{a}$ & 35.9 & 35.9 & 34.9 & 34.9 & 33.5 \\
\hline $6 a$ & 38.8 & 38.7 & 38.6 & 38.5 & 38.4 \\
\hline $7 \mathrm{a}$ & 129.3 & 129.4 & 129.7 & 127.0 & 130.8 \\
\hline $8 \mathrm{a}$ & 139.3 & 139.3 & 138.1 & 138.3 & 136.9 \\
\hline $9 \mathrm{a}$ & 47.2 & 47.2 & 46.3 & 46.3 & 46.8 \\
\hline $10 \mathrm{a}$ & 62.1 & 62.1 & 61.9 & 61.9 & 61.4 \\
\hline $11 \mathrm{a}$ & 168.4 & 168.0 & 168.0 & 168.1 & 167.3 \\
\hline 11a-OMe & 50.3 & 50.3 & 50.4 & 50.4 & 51.3 \\
\hline 1 'a & - & - & 98.9 & 98.9 & 96.1 \\
\hline 2’a & - & - & 73.4 & 73.4 & 70.7 \\
\hline $2 \mathrm{a}^{\prime}-\mathrm{OAc}$ & & & & & 20.3 and 169.1 \\
\hline 3 'a & - & - & 76.4 & 76.4 & 72.5 \\
\hline 3'a-OAc & & & & & 20.6 and 170.2 \\
\hline 4'a & - & - & 70.1 & 70.0 & 68.1 \\
\hline 4'a-OAc & & & & & 20.7 and 169.4 \\
\hline 5 'a & - & - & 77.0 & 77.0 & 72.1 \\
\hline 6’a & - & - & 61.3 & 61.3 & 61.7 \\
\hline 6’a-OAc & & & & & 20.7 and 170.6 \\
\hline $1 b$ & 96.3 & 96.8 & 96.8 & 96.9 & 90.7 \\
\hline $3 b$ & 153.2 & 152.2 & 152.2 & 152.3 & 151.1 \\
\hline $4 b$ & 110.2 & 111.0 & 111.0 & 111.2 & 111.8 \\
\hline $5 b$ & 36.0 & 35.0 & 35.0 & 35.2 & 33.7 \\
\hline $6 b$ & 38.7 & 38.6 & 38.2 & 38.4 & 31.2 \\
\hline $7 b$ & 129.7 & 129.9 & 130.0 & 129.7 & 31.8 \\
\hline $8 b$ & 139.1 & 138.4 & 138.3 & 143.3 & 36.2 \\
\hline $9 b$ & 47.0 & 46.0 & 45.9 & 45.7 & 42.0 \\
\hline $10 b$ & 62.5 & 62.3 & 62.3 & 60.0 & 16.0 \\
\hline $11 b$ & 167.6 & 167.3 & 167.4 & 167.5 & 166.4 \\
\hline $10 b-O A c$ & 171.3 & 171.4 & 171.4 & - & - \\
\hline $10 b-O A c$ & 19.4 & 19.4 & 19.4 & - & - \\
\hline $1^{\prime} b$ & - & 99.0 & 99.2 & 99.2 & - \\
\hline $2^{\prime} \mathrm{b}$ & - & 73.4 & 73.5 & 73.5 & - \\
\hline 3 'b & - & 76.5 & 76.5 & 76.5 & - \\
\hline $4^{\prime} \mathrm{b}$ & - & 70.1 & 70.1 & 701 & - \\
\hline
\end{tabular}



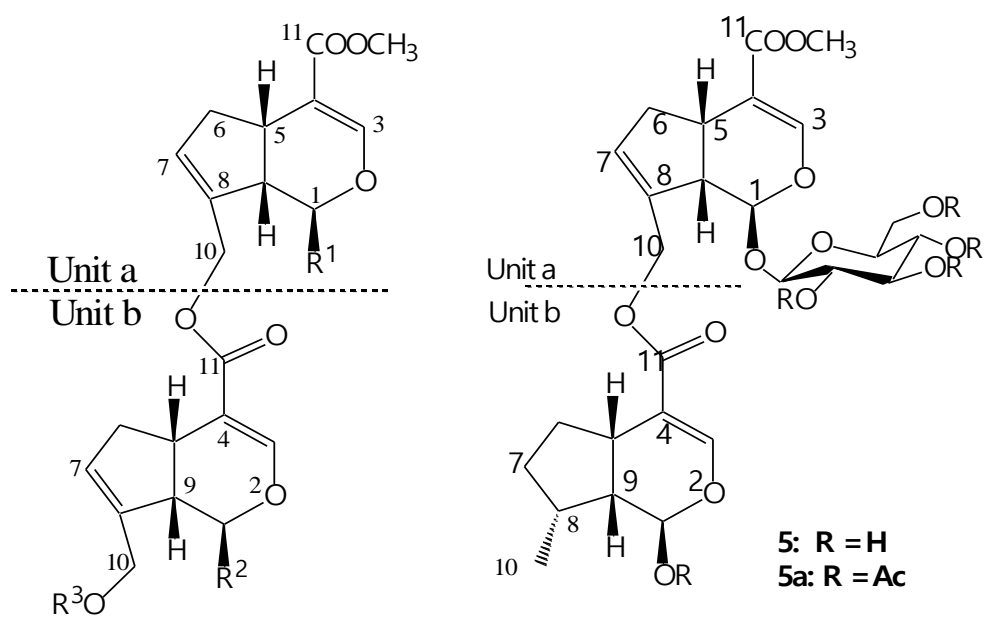

$\begin{array}{llll} & \mathbf{R}^{\mathbf{1}} & \mathbf{R}^{\mathbf{2}} & \mathbf{R}^{\mathbf{3}} \\ \mathbf{1} & \mathrm{OH} & \mathrm{OH} & \mathrm{Ac} \\ \mathbf{2} & \mathrm{OH} & O \text {-Glc } & \mathrm{Ac} \\ \mathbf{2 a} & \mathrm{OAc} & O \text {-GlcAc } & \mathrm{Ac} \\ \mathbf{3} & O \text {-Glc } & O \text {-Glc } & \mathrm{Ac} \\ \mathbf{4} & O \text {-Glc } & O \text {-Glc } & \mathrm{H}\end{array}$<smiles>[R]C1C[C@]([R20])(C)[C@H]2[C@@H]([R])OC=C(C(=O)OC)[C@H]12</smiles>

$\begin{array}{llll} & \mathbf{R}^{\mathbf{1}} & \mathbf{R}^{\mathbf{2}} & \mathbf{R}^{\mathbf{3}} \\ \mathbf{6} & \beta-\mathrm{OH} & \mathrm{OH} & \mathrm{H} \\ \mathbf{6} & \alpha-\mathrm{OH} & \mathrm{OH} & \mathrm{H} \\ \mathbf{6 a} & \beta-\mathrm{OAc} & \mathrm{OH} & \mathrm{H} \\ \mathbf{7} & \beta-\mathrm{OH} & \mathrm{H} & \mathrm{H} \\ \mathbf{7} & \alpha-\mathrm{OH} & \mathrm{H} & \mathrm{H} \\ \mathbf{7 a} & \beta-\mathrm{OAc} & \mathrm{H} & \mathrm{H} \\ \mathbf{7 b} & \beta-\mathrm{OAc} & \mathrm{H} & \mathrm{Ac} \\ \mathbf{8} & \beta-O-\mathrm{Glc} & \mathrm{H} & \mathrm{H} \\ \mathbf{9} & \beta-O-\mathrm{Glc} & \mathrm{OH} & \mathrm{H}\end{array}$<smiles>C=C(C)C1CC[C@]2(O)CC[C@]3(C)C(CCC4[C@@]5(C)CC[C@@H](O)C(C)(C)C5CC[C@]43C)C12</smiles>

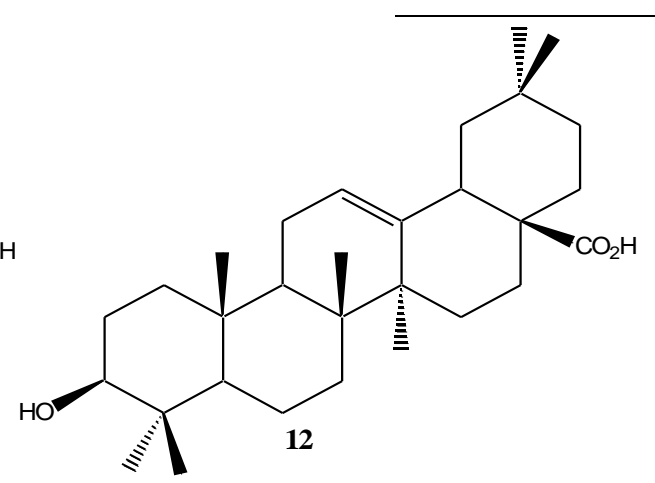

Fig. 1. Chemical structure of the isolated compounds (1-12). 